\title{
Paideusis
}

\section{So Much Truth, so Much Being: Poetic Provocations to Philosophical Musings}

\section{Daniela Bouneva Elza, Robert Manery and Avraham Cohen}

Volume 16, Number 2, 2007

URI: https://id.erudit.org/iderudit/1072580ar

DOI: https://doi.org/10.7202/1072580ar

See table of contents

Publisher(s)

Canadian Philosophy of Education Society

ISSN

0838-4517 (print)

1916-0348 (digital)

Explore this journal

Cite this article

Elza, D., Manery, R. \& Cohen, A. (2007). So Much Truth, so Much Being: Poetic Provocations to Philosophical Musings. Paideusis, 16(2), 55-72.

https://doi.org/10.7202/1072580ar
Article abstract

This bricolage of verses and prose, addresses the themes of poetics in and of philosophizing, and brings poetic provocations to philosophical musings. Authors muse on what it is to philosophize in the mood and mode of poetics, and why that matters for Education. Preliminary incursions are made into the issues of entrenched dualism between intellect (mind) and senses (heart), and ensuing privileging of the former over the latter. A collegially written introduction sets the general framework. (c) Daniela Bouneva Elza, Robert Manery, Avraham Cohen, 2007

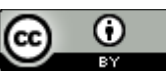

This document is protected by copyright law. Use of the services of Érudit (including reproduction) is subject to its terms and conditions, which can be viewed online.

https://apropos.erudit.org/en/users/policy-on-use/ 


\section{So Much Truth, so Much Being: Poetic Provocations to Philosophical Musings}

\author{
DANIELA ELZA \\ Simon Fraser University \\ Canada
}

\author{
ROBERT MANERY \\ Simon Fraser University \\ Canada
}

\author{
AVRAHAM COHEN \\ City University of Seattle \\ Vancouver, Canada
}

This bricolage of verses and prose, addresses the themes of poetics in and of philosophizing, and brings poetic provocations to philosophical musings. The authors muse on what it is to philosophize in the mood and mode of poetics, and why that matters for education. Preliminary incursions are made into the issues of entrenched dualism between intellect (mind) and senses (heart), and ensuing privileging of the former over the latter. A collegially written introduction sets the general framework.

\section{Framing Our Bricolage}

The ancient quarrel between philosophers and poets as portrayed by Plato (1966) in the Republic is still very much alive today. Of many forms of animosity the quarrel takes, there is first of all the separation of philosophy as a "rational," "logical," or "left brain" activity from poetry as "non-rational" or even "irrational," "non-logical," or "right brain" activity. It also takes the form of separating intellect from emotion, science from arts, facts from values, fight of debate from flight of fancy, argumentation from reverie, analysis from intuition, and so on. Not only do we separate these functions, but also we then proceed to privilege one side of functions over the other. Philosophy, once known as the "Queen of All Sciences," still behaves like one today and has identified itself with the rational side, with an unbecoming pride of place. But philosophy is far more than and far greater than this one-sided portrayal. Philosophy need not be and must not be only identified with the rational, logical, and analytic side, notwithstanding Plato's mission of banishing poets from the Republic of Philosophers.

Erizim Kohák (1984), the Czech ecological philosopher, reminds us about the birth of Ancient Greek philosophy: that she was the daughter of techne and poiesis. He likens techne to the bright daylight that shows everything in clear and distinct details. Techne, representing the masculine aspect, brings to the world "the precision of analysis and the artifice of constructs" (Kohák, 1984, p. 32), rendering it fit for human action and manipulation. In contrast, poiesis, the feminine aspect, is likened to the soft darkness of night-time that fuses all shapes into vast oneness. In the world given to us by the night vision, "[n]othing is left to do, to say: a human can only stand in silent awe and thanking devotion before the immense wonder of it all" (Kohák, 1984, p. 32). Night is the time of poetry-of deep dreams. Philosophy, Kohák tells us, takes up the intermediate vision between techne and poiesis. Such vision is best had in twilight. Yet, twilight is typically not the light condition of the academy, whose patron saint seems to be Descartes with his rallying cry of clear and distinct ideas to be revealed

(C) Copyright 2007. The authors, Daniela Elza, Robert Manery and Avraham Cohen, assign to Paideusis the right of first publication and educational and non-profit institutions a non-exclusive license to use this document for personal use and in courses of instruction provided that the article is used in full and this copyright statement is reproduced. Any other usage is probibited without the express permission of the authors. 
by the bright searchlight of logical analysis, notwithstanding the irony here of his own propensity to have vivid dreams and exalt poetry! Our effort in this piece shall be an attempt to tone down the blindingly bright light of the academy and its shrill intellectualism so that we can philosophize in twilight and "see and grasp the sense of being" (Kohák, 1984, p. 33) and the intrinsic worth of beings (Bai, 2003). We shall learn to soften our gaze and open our consciousness to the evocative presence of Being.

Our proposal to bring poetics into the heart of philosophy is, of course, not new. Both in East and West, we encounter numerous examples of philosophers who practiced and advocated poetics in philosophizing. Socrates was never too far from the evocation of the Daimon, and was seen not infrequently in a state of trance. In the Far Eastern philosophical traditions of Dao and Zen ${ }^{1}$, philosophy and poetics never separated, for they merged in the Daoist practice of nonduality (Bai, \& Cohen, in press). Consider the Lao Tzu's (2003) text, the Dao De Jing: is it poetry or philosophy? To say it's the former would be tantamount to denying that the ancient Chinese had philosophy at all! What an error of judgment that would be! Fast-forward to our own time, Martin Heidegger (1971) worries about our increasing instrumental relationship with the world and ensuing alienation. He contends that for humans to make sense of this universe and to feel "at home", we need to dwell poetically. Gaston Bachelard (1969) is another Western philosopher who gives a demonstration of poetic reverie as a philosophical (phenomenological) method.

What follows is a textual bricolage of three fragments that were presented as a panel at the Annual Conference of the Canadian Philosophy of Education Society (as part of the Canadian Society for the Study of Education conference) on the theme of poetics in and of philosophizing. Our panel was an attempt to bring poetic provocations to philosophical musings. Each of us three panelists mused on what it is to philosophize in the mood and mode of poetics, and why that matters for education. In the introduction to our presentation, we declared: "Our panel will do more than discursively invoke these poetically dwelling philosophers and traditions; we will theoretically frame our session and argue for the integration of poetics into philosophy. Evocation will follow invocation. We on the panel are poets, practitioners of Zen and Dao, and denizens of the margins, who live the life of poetics, and the poetic life, in the midst of our philosophizing, and who philosophize through our poetics. We will bring to the panel our own poetry and inspired words to evoke the poetics of philosophy. This proposal itself is a piece of reverie, and we shall see what fantastical opportunities to philosophize emerge from it."

\footnotetext{
${ }^{1}$ Not many are aware of the original meaning of 'zen'. This Japanese word consists of a Chinese character, 禪, that is derived from the Sanskrit word dhyana (jhana in Pali), meaning 'the state of absorption' as in trance or meditation (see Nyanatiloka, 1946/1970, p. 70).
} 


\title{
Toward a Pedagogy of the Imagination
}

\author{
Daniela Bouneva Elza
}

"To begin with

all words do an honest job

in our everyday language,

and not even the most ordinary

among them, those that are attached

to the most commonplace realities,

lose their poetic possibilities

as a result of this fact."

—Gaston Bachelard (1964)

"Words-

I often imagine thisare little houses, each with its cellar and garret.

Common-sense lives

on the ground floor.

...To mount and descend

in the words themselves-

this is a poet's life.

...Must the philosopher alone

be condemned by his peers

to live on the ground floor?

—Gaston Bachelard(1964) 


\title{
emergent river of meaning $^{2}$
}

"the image is an emerging of meaning" - Paul Ricoeur

"five lines become eight fourteen the movement of a river rushing to sea."

\author{
the image \\ in the eye \\ is an emerging of meaning \\ of the sunset. the egret \\ taking off \\ left \\ the footprints \\ in sand \\ (in the thickness of \\ imagining \\ fresh fallen leaves- \\ the pulse of \\ hands taking \\ the earth. \\ opens a gap \\ in the logical \\ and we are \\ the egret \\ lifting off \\ the pageholding \\ our breath \\ in forms \\ five lines become eight fourteen \\ the movement of a river rushing to sea.
}

-Zhang Er

2 emergent river of meaning was first published in Contemporary Verse 2, 29 (3), 41.

http://www.contemporaryverse2.ca/home.html 
"a single word might fill the air with birds" "... twilight, the river, a late mirror" -Pain not Bread

\title{
an introduction to semantic collapse ${ }^{3}$
}

\author{
inside the collapse \\ of the literal \\ through play \\ emerges \\ semantic \\ proximity \\ through \\ deviance \\ a single word might fill the air with birds \\ clarity \\ $*$ \\ Semantic \\ twilight, the river, a late mirror \\ lacuna
}

throw a word in the gap

(a proposition

watch

the fireworks

this (seeing as

\footnotetext{
3 an introduction to semantic collapse was first published in Contemporary Verse 2, 29 (3), 42.
} http://www.contemporaryverse2.ca/home.html 
"The image offered us by reading the poem now becomes really our own. It takes root in us. It has been given us by another, but we begin to have the impression that we could have created it, that we should have created it. It becomes a new being in our language, expressing us by making us what it expresses; in other words, it is at once a becoming of expression, and a becoming of our being."

-Gaston Bachelard (1964)

\title{
(of non-verifiable truths 3
}

\author{
each one of us is the beginning \\ of a city. we cannot ignore \\ to dwell in it. \\ (for the language \\ pyramids of needs \\ the existence of temples \\ justify \\ and order. \\ the stone makes visible \\ what a word has already stolen \\ out of thin air \\ we fall (a snowflake \\ our words ) \\ re-drawn re-constructed by other.s \\ to live \\ (as if \\ one snowflake makes a winter \\ (is what we do- \\ a slow down to earth melting \\ in palms and mirrors \\ (a round memory \\ of cherry blossoms. \\ on the tongue \\ the way knowing holds \\ (knowing \\ the transformation \\ in the holding \\ (the blooming after.
}


"Space that has been seized by the imagination cannot remain indifferent."

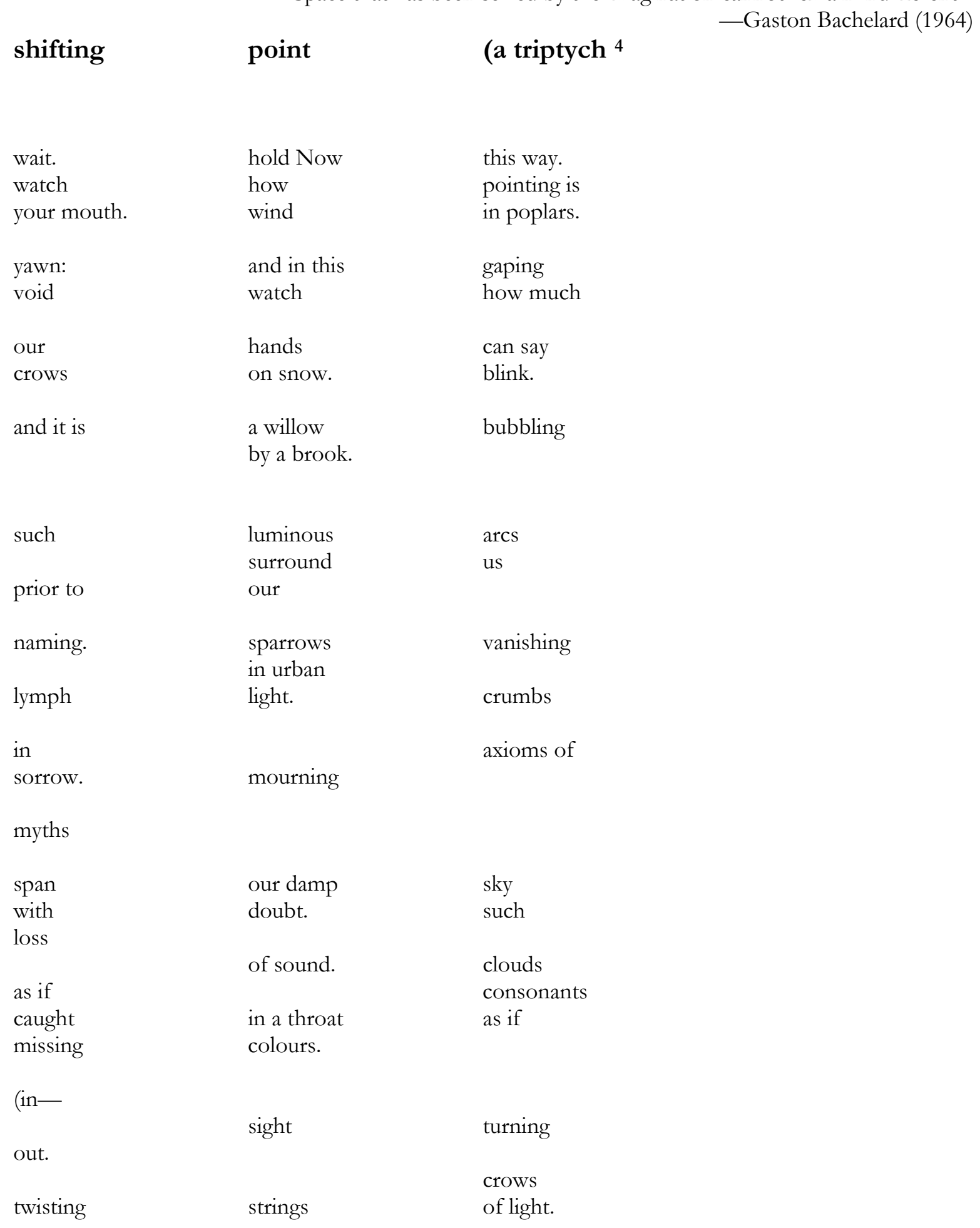

${ }^{4}$ shifting point (a triptych first appeared in Existere, 26 (2) as first place winner in their contest "can we exist without Es" http://www.yorku.ca/existere/ 
“. . . not only poetry but literature in general implies a mutation in the use of language. This redirects language toward itself to the point that language may be said, in Roland Barthes' words, to 'celebrate itself rather than to celebrate the world."-Paul Ricoeur

"He loved this part of the city, the evening streets an extension of his limbs."-Michael Ondjaate

\section{in the skin of the city}

he loved this part of

the tap-tap of

on cardboard

reverberating

on roof tops

on street lights

(in-sight-

the movement

of rain

(in-words)

the emptying

a deepening

(is poetry

a mutation
where the lamps are
the image of rain
between side-
of distances the stre
bridging the split-
he loved this part of the city
the poet speaks (of being
a space where
washes away
right underneath
an extension

"The poet speaks on the threshold of being."

—Gaston Bachelard (1964)

“The lamps are broken time."-Alan Davies

the city
rain drops
on copper

through walls of streets

dichotomy.

in language?

broken time

caught

walks

reference-

(the evening)

on the threshold

rain repeats itself

his footprints from

him. streets

of his limbs. 
"I hear the cane falter on a step of the stairs, the body that makes itself secure, sighing, the door opening, the dead man coming in. Between a door and dying there is little space, and there's hardly time enough to settle in,"

\section{a meta eulogy 5}

the dead man

how small coming in.

a metaphor is

contradictions.

the stairs

our small gestures

sighing

lyric distances

invites

the door opening,

the dead man coming in Remembering that

which never happened

between a door and dying there is

little space

a yellow threshold where The image

raps its rhythms with a wooden spoon

calls us by (name

and there is hardly time enough

to settle in.

\footnotetext{
5 a meta eulogy was first published in Contemporary Verse 2, 29 (3), 43. http://www.contemporaryverse2.ca/home.html
} 


\title{
The Call to Respond, the Call to Responsibility
}

\author{
Robert Manery
}

Lately, I have been thinking about the ethical dimension of literature. There have been a number of theorists who have written about narrative literature and ethics (e.g., Nussbaum, Ricoeur), but it seems few have examined how lyric poetry (especially the modern lyric) contributes to ethical understanding. However, there are a couple of exceptions to this silence that suggest possible openings into a dialogue between the lyric and ethics. Both Levinas and Gadamer have found a contemporary exemplar for their philosophical inquiries in the poetry of Paul Celan. Predictably, their responses to Celan have been radically different.

Gadamer wrote a number of essays on Celan's work. Though he did not explicitly discuss ethics, these essays suggest an ethical relationship between the "I" and the "You" of the poems that Gerald Bruns names a "Poetics of Intimacy" (Bruns, 1997, p. 15). Gadamer's reading of Celan's "Atemkristall" cycle investigates the question of address in these poems. Gadamer maintains that, while the "I" and the "You" of the poems are not elided, the reader must occupy, at times, the position of the speaker of the poem, to become "equally implicated" (Gadamer, 1997, p. 69) in the poem.

Levinas also wrote on the work of Celan, though his attention is focused on Celan's "Meridian Speech," Celan's most sustained discussion of poetry and art, rather than on Celan's actual poetry. Levinas saw Celan's work in terms of Levinas' own conception of ethical alterity. The poem reaches out towards the Other, "for-the Other," a reaching that necessarily involves a "responsibility for the neighbour" (Levinas, 1987, p. 100). For Levinas, the address of the poem is first and foremost an ethical relation, one that calls one to responsibility.

Bruns regards Levinas' discussion as a reductive "appropriation" that is explicitly opposed to any account of the poem couched in a Heideggerian ontology. Bruns (1997) claims the importance of Gadamer's study is that "it helps us to understand the reductions in each of these appropriations," (p. 26) reductions to ethical alterity or to Heideggerian ontology, since Gadamer's account requires neither ethics nor ontology. It seems a difficult task to see Gadamer's readings as being in any way independent of an ontological account of the poem. Despite this opposition, however, I want to look at Gadamer's readings of Celan's poems alongside Levinas' to create space for these "appropriations" as possibilities rather than reductions. Both accounts are concerned with the question of address. For Levinas, the relation toward the Other is always already an ethical relationship where one is called to responsibility by the Other (Levinas, 1981). For Gadamer, to allow oneself to be addressed by the Other (the poem) is to put oneself in a position of responsibility toward the Other (Grondin, 2003, pp. 100-110).

For the remainder of my fragment, I want to create a mosaic of words by juxtaposing passages from Levinas, Gadamer, and Celan in order to present the ethical relation involved in the reading of lyric poetry.

\section{Gadamer on Celan:}

Readers of lyric poetry always already understand in a certain sense who I is. Not just in the trivial sense of knowing that it is always the poet who speaks, rather than a speaking person introduced by him. Beyond that, readers also know what the poet-I actually is. For the I pronounced in a lyric poem cannot be conclusively limited to the I pronounced in a lyric poem cannot be conclusively limited to the I of the poet, which would be different from that of the I-pronouncing reader. Even when the poet is 'cradled in his characters,' expressly separating himself from the 'instantly mocking' crowd, it is as if he no longer means himself, but rather also includes the reader in his I-character, separating him or her from the crowd in the same way he knows himself to be. This is especially true with Celan, where 'I,' 'you' and 'we' are pronounced in an utterly direct, shadowy-uncertain and 
constantly changing way. This I is not only the poet, but even more so 'that individual' [jener Einzelne], as Kierkegarrd named the one who is each of us.

(Gadamer, 1997, p. 69)

Now, Levinas on Celan:

A language of nearness for nearness's sake, more ancient than that of the truth of being - which it probably bolds and upholds. The first among languages, an answer preceding the question, a responsibility for the neighbour, making possible, by its for-the-other, all the wonder of giving. (Levinas, 1987, p. 100)

\section{Now, Celan: "Letter to Hans Bender":}

Only truthful hands write true poems. I cannot see any basic difference between a handshake and a poem. (Celan, 1986, p. 26).

Celan, again: "Atemkristall”

BY THE UNDREAMT etched,

the sleeplessly wandered-through breadland

casts up the life mountain.

From its crumb

you knead anew our names,

which I, an eye

similar

to yours on each finger,

probe for

a place, through which I

can wake myself toward you,

the bright

bungercandle in mouth.

\section{More Celan: “The Meridian”:}

The poem intends another, needs this other, needs an opposite. It goes toward it, bespeaks it.

For the poem everything and everybody is a figure of this other toward which it is heading.

(Celan, 1986, p. 49)

\section{Back to Levinas:}

The inescapable: the interruption of the playing order of the beautiful, and of the game of concepts of the jeu du monde; the interrogation of the Other, a search for the Other. A quest consecrating itself in a poem to the Other: a song rises in the giving, in the one-for-the-other, in the very significance of the signification. A signification older than ontology and the thought of being - and one which knowledge and desire, philosophy and sexuality, presuppose.

(Levinas, 1987, p. 104) 
Back to Gadamer:

Who the You is cannot be determined because it hasn't been determined. The address has an aim, but it has no object - other than perhaps whoever faces up to the address by answering.

(Gadamer, 1997, p. 69).

Back to Celen: “Atemkristall”:

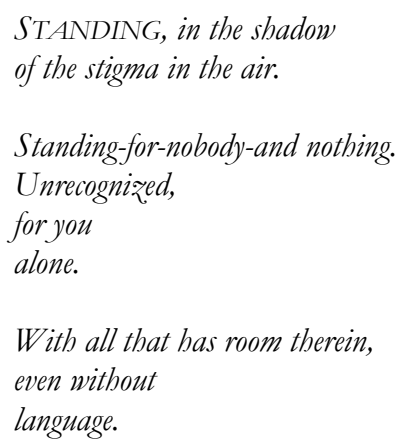

\title{
Academic Death ${ }^{6}$
}

\author{
Avraham Cohen
}

I really do think with my pen, for my head often knows nothing of what my hand is writing.

—Ludwig Wittgenstein (1998, p. 24)

\section{Academic/Death Comes Running}

The news arrives,

/ will be dying.

I run

I must finish my work.

The academy becomes very human,

Special arrangements are made.

6 All poems by the author in this part of the manuscript were previously published in the author's doctoral dissertation (Cohen, 2006) 
Even the President of the University

Ifeel my body move.

All there...

Death creates human flesh out of the institutional skeleton.

I die before / die.

Join me here

Feeling deep emotion.

In the heart of the matter...

Learning to hear the sound of my beating Heart,

Engaging senses,

Smelling the Blood of my Heart,

Tasting the Blood,

Becoming Blood...

\section{In the midst of the silence of the Way.........}

-a. cohen

Leonard was kind enough to respond:

Dear Roshi,

I'm sorry that I cannot

help you now, because

I met this woman.

Please forgive my

selfishness.

I send you birthday greetings,

deep affection and

respect

Jikan

the useless monk

bows his head. (Cohen, 2006, p. 23)

\section{Ranting Against the Storm}

Was school ever fun? When did we forget curiosity and replace it with knowledge accumulation? Is job readiness really the most important learning outcome? How and when did security become equated with wealth accumulation? How did teachers come to forget about awe and delight and become the minions of the state and technology? Of course, I'm not talking about all teachers. There are still a small minority living out and beyond the margins, who prefer, or choose, or who have no choice, who live dangerously.

Against the storm of institutional and systemic pressure, some teachers work and live courageously; holding true to an inner compass and reaching for the hearts of their students. In my 
other life as a psychotherapist I see teachers in my private practice. The truth is that those who have support from educational leaders within their schools do not come to see me about their pain related to teaching, but within my experience these are the rare exceptions. And, educational leaders who come to see me are almost invariably speaking about the personal and professional cost of supporting a more heartfelt and poetic environment in their school. In the tradition of Socrates there are still a few educators who can and do stir up the youth and the youth-fullness of the elders; a rewarding and potentially life and career threatening endeavor.

To live poetically does not require that you be a poet. It does require honesty about yourself, authenticity, and a willingness to be seen in the beauty of your own nakedness. Poetic educators are vulnerable, which does not mean that she is a walking wound. What it means is that she is open, receptive, and feeling. These teachers, like poets, are in touch with the Muse. And like poetry well done, teaching well done is not done at all. It emerges. The Muse stirs. The poet/teacher is the vehicle of delivery. Her job is to step aside and allow the muse to sing. Many educators have lost touch with their Muse. The systemic pressure against musing and reverie is immense. And, there are teacher educators such as Carl Leggo (2006):

I invite other teachers who pursue studies at the University of British Columbia to engage in researching their daily experiences by writing creatively and narratively and poetically about their lives, to research their lived experiences in order to pursue creative processes of transformation.

(Leggo, 2006, p. 2)

I too wait and watch, my image upside down in the smooth river, all the world topsy turvy but still in balance, learning to be still, even in a vertiginous world.

this is the teacher's way

(Leggo, 2006, p.5)

The life force may be covered but surely its pulse is still throbbing. Here is a little haiku-like poetry to accentuate the throb rate:

\author{
Opening \\ The Gateway opens \\ A subtle breeze comes through \\ The World changes, \\ Forever. \\ -Lao-Tzu's Mother ${ }^{7}$ \\ -a. cohen
}

7 These lines, including the source, emerged spontaneously during my regular practice of meditation on the morning of March 19, 2006. Meditation is for me a playful and creative practice. 


\section{The Fine Line}

On one side of the edge or another

Each person resides.

From one side everything is known

And taken for granted.

-a. cohen

\section{On the Edge}

Feelings are troubling, vision unclear.

$$
\begin{aligned}
& \text { On the far side } \\
& \text { Another person emerges } \\
& \text { And the unseen world } \\
& \text { Is seen. } \\
& \text { - a. cohen }
\end{aligned}
$$

\section{$\mathrm{N} / \mathrm{o} / \mathrm{ne}$ is More}

No chicken,

No egg,

Noflesh,

Nobones,

$$
\begin{aligned}
& \text { No Nothing. } \\
& \text {-a.cohen }
\end{aligned}
$$

$$
\begin{aligned}
& \text { No-Thing } \\
& \text { /was no-thing } \\
& \text { / will be no-thing } \\
& \text { Jam no-thing. } \\
& \text { Who writes? } \\
& \text {-a. cohen }
\end{aligned}
$$

\section{One}

The sound of one hand clapping

Is not so awesome as it used to be.

Inow listen for the sound of 


$$
\begin{gathered}
\text { Ten thousand hands clapping as One. } \\
\text {-Lao-Tzu's Protégé8 } \\
\text {-a.cohen }
\end{gathered}
$$

$$
\begin{gathered}
\text { Wind } \\
\text { A student says, } \\
\text { Ifeel a still warm wind, and } \\
\text { My longing reaches toward you. } \\
\text { An educator says, } \\
\text { Ifeel a still warm wind, and } \\
\text { My longing reaches toward you. } \\
\text {-a. cohen }
\end{gathered}
$$

\section{Breeze}

I blow through you

Leaving no trace

$$
\text { Yet you know l've been here. }
$$

$$
\begin{gathered}
\text {-Lao-Tzu's child } \\
\text { - a. cohen }
\end{gathered}
$$

I have no words, and yet above lie my words, while something called me sits here, below.

$* * * * * * * * * * * * * * * * * * * * *$

\section{Concluding, together: Being and Non-being in Saskatoon}

The structuring of our dwelling places is interactive with our individual and collective consciousness and guides and shapes the way we interact with each other in the visible world. The way we practice philosophy articulates our relationship with the world and our purpose in it, as well as our numerous and diverse response to the 'other.' It was a pleasure to philosophize poetically at the Canadian Philosophy of Education Society's meetings. Whoever thought that we could philosophize by reading our poetry in these philosophy sessions? But we knew philosophy was so much more than discursivity

8 This emerged from the same source as footnote number 3, also in March, 2006.

9 Also, from the same source as footnote number 3 in March, 2006. 
and argumentation. Philosophy is, as Hadot (1995) reminds us, a way of life. At the early hour of our morning session, the room was filled with life: breath added to the energy of images, laughter, a sun beam at the right time, a red wall, and a bit of magic bound those in the room together in Saskatoon. "And what is more," Bachelard reminds us, "the imagination, by virtue of its freshness and its own peculiar activity, can make what is familiar into what is strange. With a single poetic detail, the imagination confronts us with a new world" (1964, p.134). For those who were not there (you will just have to take our words for it), we have offered you above the textual form of our musings and now this haiku:

\author{
Being and Non-being in Saskatoon \\ Prairie land flat \\ We see far. \\ On-line text \\ Outer reading/inner seeing. \\ This Becoming.
}

\title{
Acknowledgement
}

We would like to acknowledge Heesoon Bai for initiating this project, gathering us up, and involving us in the Poetics and Philosophy panel from which this collaborative paper emerged.

\section{References}

Bachelard, G. (1964). The poetics of space. (D. Russell, Trans.). Boston, MA: Beacon Press. (Original work published 1960)

Bachelard, G. (1969). The poetics of reverie: Childhood, language, and the cosmos. Boston, MA: Beacon Press.

Bai, H. (2003). Learning from Zen arts: A lesson in intrinsic valuation, Journal of the Canadian Association for Curriculum Studies, 1(2), 1 - 14.

Bai, H., \& Cohen, A. (in press). Breathing qi, following Tao: Transforming this violence-ridden world. In C. Eppert \& H. Wang (Eds.), Cross-cultural studies in curriculum: Eastern thought and educational insights. Mahweh, NJ: Lawrence Erlbaum.

Bruns, G. (1997). The remembrance of language: An introduction to Gadamer's poetics. In H. Gadamer, Gadamer on Celan: "Who am I and who are you?" and other essays. (Richard Heineman \& Bruce Krajewski, Trans. and Eds.; pp. 1-51). Albany, NY: State University of New York Press.

Celan, P. (1986). Collected prose. (R. Waldrop, Trans.). St. Paul: Sheep Meadow Press.

Cohen, A. (2006). Attending to the inner experience of an educator: The human dimension in education (Doctoral dissertation, University of British Columbia). Dissertation Abstracts. [Electronic version] http://hdl.handle.net/2429/63 .

Cohen, L. (2006). Book of longing. Toronto, ON: McLelland \& Stewart.

Davies, A. (1982). Active 24 hours. New York: Roof Books/Segue Foundation.

Gadamer , H.. (1997). Gadamer on Celan: "Who am I and who are you?" and other essays. (Richard Heineman \& Bruce Krajewski, Trans. and Eds.). Albany, NY: State University of New York Press.

Hadot, P. (1995). Philosophy as a way of life (A. I. Davidson, Trans.). Oxford: Blackwell Publishers.

Heidegger, M. (1971). Poetry, language, thought, New York: Harpers and Row.

Kohák, E. (1984). The embers and the stars: A philosophical inquiry into the moral sense of nature. Chicago: University of Chicago Press.

Lao Tzu. (2003). Dao De Jing: Making life significant (R. Ames \& D. L. Hall, Trans.). Toronto, ON: Random House. 
Leggo, C. (2006, June). The teacher as poet-researcher. Ejournal: BC Educational Leadership Research. (http://slc.educ.ubc.ca/eJournal/Issue6/index.htm). (6)

Levinas, E. (1987). From being to the other: Paul Celan. (R. Bringhurst, Trans.). Descant, 18(4), 99-105.

Ondaatje, M. (1987). In the skin of a lion. Toronto, ON: McClelland \& Stewart Inc.

Pain not Bread (2000). Introduction to the introduction to Wang Wei. London, Ontario: Brick Books. (Pain not Bread is a collaborative writing group formed in 1990 by Roo Borson, Kim Maltman, and Andy Patton.)

Paz, O. (1973). Early poems 1935-1955. New York: New Directions.

Plato. (1966). Plato's Republic (I. A. Richards, Trans.). Cambridge, UK: Cambridge University Press.

Ricoeur, P. (1978). The metaphorical process as cognition, imagination, and feeling. Critical Inquiry, 5 (1), 143-159.

Wittgenstein, L. (1998). Culture and value. (von Wright, G. H., ed., \& P. Winch, trans.; rev., 2nd ed.). Oxford: Blackwell.

\section{About the Authors}

Daniela Bouneva Elza is a Ph. D. student in the Faculty of Education at Simon Fraser University. Her research interests are in creativity, bridging the theory-practice divide, alternative methods of inquiry, imagination, deviance, and more specifically in metaphor, and how metaphor shapes our knowing. Her work has appeared in The Capilano Review, Contemporary Verse 2, Quills, Existere, Paideusis, Room of One's Own, The Arabesque Review, and is forthcoming this summer in dANDelion. She can be reached at daniela@livingcode.org.

Avraham Cohen, Ph.D., RCC, CCC is in private practice (counselling and psychotherapy) and teaches at City University of Seattle, in Vancouver BC. He has published widely, including peer reviewed academic journals, and regularly presents at educational and counselling conferences. Contact information: acohen@cityu.edu.

Robert Manery is a Ph. D. student in the Faculty of Education at Simon Fraser University. His research interests include hermeneutics, moral philosophy, and teacher education. A volume of poetry, /It's not as if it hasn't been said before,/ was published in 2001 by Tsunami Press.

Robert can be reached at rmanery@sfu.ca. 